\title{
Investigating Factors that Influence Malaysian Auditors' Ethical Sensitivity
}

\author{
Razana Juhaida Johari * \\ Faculty of Accountancy \& Accounting Research Institute \\ Universiti Teknologi MARA \\ Shah Alam, Malaysia \\ Email: razana@salam.uitm.edu.my
}

Md. Mahmudul Alam

School of Economics, Finance and Banking

Universiti Utara Malaysia

E-mail: rony000@gmail.com

Jamaliah Said

Accounting Research Institute

Universiti Teknologi MARA

Shah Alam, Malaysia

Email: jamaliah533@salam.uitm.edu.my

*Correspondent author

\section{Citation Reference:}

Johari, R. J., Alam, M.M., \& Said, J. (2021). Investigating Factors that Influence Malaysian Auditors' Ethical Sensitivity. International Journal of Ethics and Systems, 37(3). 406-421. (online) https://doi.org/10.1108/IJOES-01-2021-0006

This is a pre-publication copy.

The published article is copyrighted by the publisher of the journal. 


\title{
Investigating Factors that Influence Malaysian Auditors' Ethical Sensitivity
}

\begin{abstract}
Purpose - The primary role of auditors is to offer fiduciary services to the society and users of the financial reporting. With this role, users placed their trust and dependent on the ability and judgment made by the auditors during their auditing works. However, recent financial scandals involving high profile companies frustrated the public's expectations, particularly in Malaysia. It is claimed that auditors are not having ethical sensitivity while executing their task in mitigating the fraudulent financial reporting. Therefore, this study aims to examine the influences of ethical orientation, locus of control and firm's ethical culture on the auditors' ethical sensitivity in Malaysia.

Methodology/approach - This study collected primary data based on a questionnaire survey among audit firms in Klang Valley area and registered with Malaysian Institutes of Accountants.

Findings - The results showed ethical sensitivity has a significant negative relationship with relativism and some cases have a significant positive relationship with idealism. Moreover, it found a significant positive relationship between ethical sensitivity and ethical culture.

Originality/value - This paper provides benefit to the audit firms, professional bodies, policy makers, and academia in understanding the factors that might increase the sensitivity of auditors in dealing with ethical issues that could lead to fraudulent financial reporting in the company.
\end{abstract}

Keywords: Ethical sensitivity; ethical culture, ethical orientation, locus of control; audit; fiduciary services; Malaysia

\section{Introduction}

The primary role of auditors is to offer fiduciary services to the society and users of the financial report (Sweeney, Arnold and Pierce, 2010). These fiduciary services create the fiduciary relationship between the auditors and users where the users must trust or depend on the ability and judgment that have been made by the auditors on the true and fair view of the audited company's financial reporting. With this role, users have high expectation of the judgement made by the auditors and that is why the auditors need to balance up their judgment for the benefit of their audit client as well as the public at large.

However, nowadays financial scandals involving high profile companies around the world, such as the famous cases of Satyam Corp and Enron outside of Malaysia and PKFZ Berhad, Transmile Corporation Berhad and Perwaja Steel Berhad in Malaysia, had frustrated the public expectation. The number of reported cases of fraud, corruption and mismanagement due to the auditors' unethical behaviour is costly, especially to the employees and society (Johari, Mohd. Sanusi and Zarefar, 2019; Yusoff, Salleh, Zakaria, Nair, Vadeveloo and Luqman, 2011). For example, in Satyam Computers' scandal that happened in India, their auditors of PricewaterhouseCoopers (PWC) were accused due to the failure to detect falsification of the company's accounts. The same issue also happened to Transmile Group Berhad in Malaysia, in which their auditor, Delloite and Touche also failed to detect the accounting irregularities during their audit. Both cases have made the company suffer losses and made the company collapsed.

There is a high possibility that auditors might be involved with unethical judgment when auditors are unaware of ethical issues that are not encountered in situation (Dreike and Mocckel, 1995). For example, after 15 years of Enron's case, it seemed that there are still a 
lot of companies that collapsed such as Perwaja Steel, Sime Darby Bank and Renong Bhd., even though the rule and regulation on Code of Ethics were being modified and strengthen. The reasons that these big companies collapsed have brought into question the status and credibility of the auditors with allegations of accountants' violations of public trust (Leung, 2006). As a result, public perceived that the auditors are unaware of the ethical implication in their technical decision and all of these financial scandals had caused a high level of accusation and criticism on the auditors. Thus, identifying the factors that influence ethical sensitivity, it may assist practitioners and educators in improving the auditor's judgment as by identifying the intention and behaviour of the auditors.

Based on the ethical decision-making model developed by Rest (1986), ethical sensitivity is the first step in ethical decision-making process. Shaub's (1993) defined ethical sensitivity as ability to recognize the ethical nature of a decision, whereas Butterfield et al. (2000, p.982) defined it as a person's recognition that his/her potential decision or action could affect the interests, welfare, or expectations of the self or others in a fashion that may conflict with one or more ethical standards. It is claimed that moral domain will not be activated unless persons are aware of it or understand that ethical problem exists (Rest, 1986; Shaub, Finn and Munter; 1993). Therefore, persons will not use ethical judgment unless they are aware that there is an ethical problem in that situation. Besides that, from a survey in 2007 by Jackling et al., they identified four factors as the top reasons of ethical failure and one of it is lack of ethical sensitivity. However, majority of the previous studies on ethical decision making only focused on the ethical judgement which is the second step in ethical decisionmaking process. Thus, this study is aimed to investigate the factors that influence auditor's ethical sensitivity.

\section{Literature Review and Hypotheses Development}

\section{Ethical Orientation and Ethical Sensitivity of Auditors}

There are a lot of definitions regarding ethical orientation. According to the Cambridge Advanced Learner's Dictionary (2008), 'ethical' can be defined as "relating to beliefs about what is morally right and wrong"; whereas orientation is "the particular preferences, tendencies, beliefs or opinion that a person has". It can be concluded from both definitions that ethical orientation is an individual's ethical philosophy which describes the beliefs of an individual either it is good and bad or right and wrong. In this study, ethical orientation can be referring as the persons beliefs either it is good or bad based on their individual characteristic's idealism or relativism.

Based on the previous studies on ethical orientation, the results found inconsistent findings regarding ethical orientation on ethical sensitivity. For example, Marques and Pereira (2009) found no relationship between ethical sensitivity and ethical orientation. In contrast, other researchers such as Uyar and Ozer (2011) found that relativism affects ethical sensitivity negatively while Shaub et al. (1993) found a relationship between ethical orientation and ethical sensitivity. In that study, they found that auditors who have high relativism and idealism seem to be less likely to detect ethical issues as compared to the auditors who are low in relativism and idealism. Moreover, the study also found that ethical orientations are influenced by the auditors' cultural environment and personal experiences. Besides that, Ismail (2014) also found a significant positive and negative impact of idealism and relativism on ethical judgment that can be related to ethical sensitivity. Johari, Mohd. Sanusi and Vincent, (2017) investigated the influence of individuals' idealism and relativism orientations on the recognition of an ethical issue and ethical intention where they suggest that idealism orientation is associated with increased ethical issue recognition; while relativism orientation is associated with decreased ethical intention. Smith (2009) found a significant positive 
relationship between idealism and ethical sensitivity, but there is no relationship found between relativism and ethical sensitivity. Ozbek (2013) supported that individuals with higher levels of ethical idealism are more likely to be aware of ethical issue (ethical sensitivity) during the study involving the marketing managers.

Therefore, based on the previous literatures, the below hypotheses are formulated:

$\mathrm{H}_{1}$ : Idealism and relativism of ethical orientation statistically significantly influence the ethical sensitivity of auditors

\section{Locus of Control and Ethical Sensitivity of Auditors}

The concept of locus of control was first introduced in 1954 by Julian Rotter (Rotter, 1966). Locus of control is defined as what people's perception of the source of control over their destiny or actions. It is how individuals judge themselves or believe that an external force, such as luck, is related or influence on events in their life (Firth, Mellor, Moore and Cloude, 2004). This definition was supported in the latest article by Chelariu, Horomnea and Tanasa, (2014) where they defined locus of control as the way of a person explains the success or failure of a certain action that can be determined through causes of internal or external nature, controllable or uncontrollable by that person. In this study, definition by Chelariu et al., are used because the objective in this study is to measure whether internal and external influence person actions.

Empirically, locus of control plays a significant relationship with ethical sensitivity. Kalbers and Fogarty (2005) found that individuals with an internal locus of control are not exposed to stress as compared to an external locus of control that is more in stressful conditions. External locus of control could reduce personal accomplishments and job performance and the probability of making mistakes in the decision could be happening because of the inability to be aware of the ethical issue. Also, Chen and Silverthorne (2008) found that individuals with high internal locus of control have higher levels of job satisfaction and performance. This in turn gives lower levels of job stress in their workplaces.

Prior studies found that auditors with internal locus of control have higher level of organizational commitment and will report the errors to increase the quality of audit (Donnelly, Quirin and O'Bryan., 2003) because the action to report the misstatement is related to ethical sensitivity before any judgment can be made (Chadegani, Muhammaddun and Mohd Iskandar., 2015). On the other hand, Paino, Smith and Ismail (2014) found that the external locus of control influenced the dysfunctional behavior.

Therefore, based on these arguments, the following hypotheses are formulated.

$\mathrm{H}_{2}$ : Internal locus and external locus of control statistically significantly influence the ethical sensitivity of auditors

\section{Ethical Culture and Ethical Sensitivity of Auditors}

In this study, definition by Ethics and Compliance Officer Association (2006) are used were they defined ethical culture as how an organization demonstrates and teaches their staff regarding its firm's values that influence employee's behaviour. The values compromised on three issues, whether employees do the right thing, do what is right and expected and ethics programs such as reward and punishment systems. Ethical culture was found to be important in order to determine the unethical behaviour where Douglas et al. (2001) and Jenkins (2008) found that ethical culture of the firm can influence the ethical decision-making process.

Based on previous studies, researchers found significant relationship between ethical culture and ethical sensitivity (Md. Zabid and Saidatul, 2008; Shu, 2006). However, the result was analysed based on different dimensions. For example, Md. Zabid and Saidatul (2008) and Shu (2006) used ethnicity as the dimension for ethical culture while Jeffry et al. (2004) used nation. Jeffry et al. (2004) examined the relationship of ethical culture on ethical sensitivity 
among Taiwanese auditors and the results showed that ethical culture had a positive influence on ethical judgments. In research by Pierce and Sweeney (2005), audit partners perceived consequences from junior auditors' actions when junior auditors did not fully perform audit work that should be done by them. These problems occurred due to 'tone at the top' that did not fully emphasise on the ethical culture in which it gave social influence pressures on the decision made by them.

Based on research by Helliar and Bebbington (2004), 42\% of respondents agreed or strongly agreed that the increasing focus in firm's success such as income aspirations focus has led to a more unethical behaviour. Jones and Thorne (2003) research focused on the influence of superiors on auditors' ethical evaluations. Based on their finding, the influence of peers has an influence on ethical behaviours of peers. Jones's findings are supported by other researchers, for example, Thorne and Hartwick (2001) who found that the improvement in auditors' ethical evaluations can be achieved by encouraging discussion of ethical issue or dilemmas with peers. In contrast, Pierce and Sweeney (2005) found that time pressure between peers moderated and influenced the relationship between time pressure and quality threatening behaviour.

Considering the influence of peers, accounting profession tends to support that the behaviour of peers has an influence on ethical behaviours. This statement was supported by Thorne and Hartwick (2001), because improvements may occur in auditors' ethical evaluations by encouraging discussion of ethical dilemmas with peers (Pierce and Sweeney, 2005). The studies conducted by Trevino, Butterfield and McCabe (1998) showed that a strong ethical culture creates a positive relationship by lower rates of observed misconduct, increases reporting of misconduct to leadership, greater satisfaction with management's response to misconduct, greater satisfaction with the organization as a whole, lowers exposure to situations inviting misconduct and increases sense of preparedness to handle situations inviting misconduct.

Therefore, by adapting the link between firms' ethical culture and ethical sensitivity, the following hypothesis is proposed:

$\mathrm{H}_{3}$ : Ethical culture influences statistically significantly influence the ethical sensitivity of auditors

\section{Methodology}

\section{Sampling and Data Collection}

The focus of this study is auditors' ethical sensitivity. Therefore, the data were collected from the auditors who worked with audit firms in Klang Valley area and registered with Malaysian Institutes of Accountants (MIA). Klang Valley has been selected for the area of this study because this area contributes the largest number of audit firms in Malaysia.

Data for this study is collected through distributing the questionnaires to the selected auditors comprised of five levels - senior, managers, partners, senior managers and audit assistants. A total of 500 questionnaires were distributed and 190 samples have responded. However, only 163 were usable with total response rate of $32.4 \%$.

\section{Measurement of Variables}

\section{Ethical Sensitivity}

Ethical sensitivity is measured through two scenarios. These scenarios were adapted from Cohen, Pant and Sharp (1992) that consisted of two ethical scenarios, i.e. (i) under reporting hours, and (ii) noncompliance issue. These issues were used to represent frequently issues occurring practices within auditing firms. All the scenarios contained elements of ethical dimension and were able to measure the level of awareness of participants (Dickerson, 2009). 
There were four questions in each of the scenario adapted from Cohen (1992) and Gholami and Tirri (2012). The respondents were asked to read these scenarios and answered the respective questions independently. The two scenarios used in this study have been tested in a variety of subjects including auditors, accounting academics and students (Johari et al., 2017; Dickerson, 2009; Cohen, Pant and Sharp, 2001).

\section{Ethical Orientation}

The measurement of ethical orientation was adopted from Ethics Position Questionnaire (EPQ) developed by Forsyt in 1980. The original measurement has 20 items that consisted of 10 items each for idealism and relativism. This study uses the adopted version of EPQ which consists of 14 items for 7 questions each on idealism and relativism. This scale has been verified in Johari et al., (2019) and Ismail (2014) in their study on the Malaysian respondents. The list of the items is given in appendix.

\section{Locus of Control}

This study adopted items developed by Spector (1988) to measure the employee's locus of control in an employment situation. Spector (1988) observed that it is preferable to use general locus of control scale when investigating behaviours of workers in an organization. The list of the items is given in Appendix.

\section{Ethical Culture}

This study adapted the measurement of ethical culture which consisted of 11 items measurement developed by Hunt, Wood and Chonko in 1989. The 11 items being measured were concerning about ethics in organization, the perceived extent when individual acts ethically and the perceived extent either firm will punish or reward for any unethical behaviour (Douglas et al., 2001).

\section{Data Analysis}

The data are analysed using descriptive statistics through demographic data. Furthermore, inferential analysis was used which comprises of reliability test, normality test, correlations and regression analysis.

\section{Results and Findings}

\section{Demographic Information}

Among the samples of the study, $46.6 \%$ were employed in small auditing firm. Medium size audit firms were the second largest employment with $35 \%$, and only $18.4 \%$ of the respondents are from the big four companies. Out of the total respondents, most of the respondents $(55.8 \%)$ of this study were female, and $46 \%$ of the total respondents were Malays, $38.7 \%$ Chinese and $15.3 \%$ of were Indians.

\section{(Insert Table I here)}

In terms of age of the respondents, $55.8 \%$ of them were between $21-25$ years, $15.3 \%$ of them were also between $26-29$ years, followed by $22.1 \%$ between $30-39$ years and $6.7 \%$ were 40 years old and above. In terms of job position, $14.7 \%$ of the respondents were partners, $12.3 \%$ were managers, $22.7 \%$ were seniors, and $50.3 \%$ were audit assistants. Regarding education. $1.8 \%$ of the respondents had diploma, $68.7 \%$ had degree, and $29.4 \%$ of them had professional qualifications. Regarding work experience, $54.6 \%$ of the respondents had 1-3 years' experience as an auditor, $19.6 \%$ had 4 to 5 years of experience, $21.5 \%$ had 6 to 10 years of 
experience, $1.8 \%$ had 10 to 15 years of experience and $2.5 \%$ had more than 15 years of job experience.

\section{Diagnostic Test}

Data Normality Test: To be considered the data as the normal distribution, the skewness must be between 1 and -1 and kurtosis falls between 3 and -3 (Hair, Black, Babin, Anderson, and Tatham., 2006). The value of skewness and kurtosis for each of the variables are within the range (Table II). Therefore, it can be considered that all of the data are normally distributed.

\section{(Insert Table II here)}

Data Reliability Test: The Cronbach's Alpha is conducted to measure the internal consistency among variables. The Cronbach's Alpha for relativism ethical orientation is 0.947 , idealism ethical orientation is 0.956 , internal locus of control is 0.723 , external locus of control is 0.740 , and ethical culture is 0.782 . Out of all the figures above, it indicates that all variables are positively contributing to the overall reliability since the Cronbach alpha is higher than 0 .70 .

Multicollinearity and Correlation Analysis: Correlation examines the relationship between two variables in a linear fashion that helps to identify whether one variable is related to another. When variables are considered highly correlated to each other such as the value of coefficient is 0.8 or above, that relationship will cause a multicollinearity problem if (Field, 2005). Here, the correlations for all of the variables are below 0.8 for both scenario 1 and 2 (Table III). Therefore, it can be concluded that there is no multicollinearity problem available in the data.

\section{(Insert Table III here)}

Moreover, multicollinearity problem can be tested if the VIF value is greater than 10 , but the VIF value for all of the variables are below 10 in both scenarios (Table II). Therefore, no multicollinearity problem exists among the variables for both of the regression models.

Factor Analysis: Factor analysis is one of the methods used to reduce the large number of variables to a smaller set of underlying factors that contained all the essential information (Pallant, 2007). This method is used in this study to identify the underlying dimensionality of locus of control, ethical orientation and ethical culture. The Kaiser-Meyer Olkin test indicates all of the value are greater than .6 and chi-square are significant at $\mathrm{p}<0.000$ (Table IV). Therefore, the sample is adequate to be used in this factorial analysis for all of the variables. Based on the factor analysis, some variables are removed in the measurement when the loading is below 0.5 . The value of the loading is given in appendix.

$$
\text { (Insert Table IV here) }
$$

\section{Regression Analysis}

The regression result shows the goodness fit of the model as the F-test is significant for both scenarios (Table V). In case of scenario 1, only relativism and ethical culture have significant relationships with the ethical sensitivity of auditors. In case of scenario 2, idealism is also found significant as well as relativism and ethical culture on ethical sensitivity of auditor.

(Insert Table V here) 


\section{Discussions of Findings}

This study is conducted to examine the relationship between ethical orientation, locus of control and ethical culture towards ethical sensitivity among the auditors in Malaysia. The questionnaires were distributed to the auditors who worked with audit firms in Klang Valley area and registered with Malaysian Institutes of Accountants (MIA). In total, 155 respondents participated in this study. Based on the correlation analysis that has been conducted, it was found that ethical sensitivity has a significant negative relationship with relativism. This means that when relativism increased, ethical sensitivity decreased. Besides that, ethical sensitivity also has a significant positive relationship with idealism. This indicated that when idealism in a person is increasing, ethical sensitivity also increases.

Whereas, based on the regression analysis, it was found that there is a significant relationship only for ethical orientation in Scenario 1. Meanwhile, in Scenario 2, it was found that there is a significant relationship for both idealism and relativism. These findings are supported by Ismail (2014) which found that a significant positive and negative impact of idealism and relativism on ethical judgment. Moreover, the result is also supported with the findings from Ozbek (2013) who stated that individuals with higher levels of ethical idealism are more likely to be aware of the ethical issue (ethical sensitivity). However, this result is inconsistent with the study from Douglas et al. (2001) that ethical judgment was only affected by ethical orientation in illegal cases only. In another study by Chan and Leung (2006), authors found that there is a significant relationship between ethical orientation and ethical sensitivity, but the relationship is too weak.

From the findings, it is understood that the individuals with relativist normally make non ethical decision more often as compared to idealism individuals. Based on both scenarios, most individuals in Malaysia are more relativist in making their decision. This situation can be seen in the real situation where there are a lot of dishonest practices by the auditors such as in cases of Transmile Group Berhad and PKNZ Berhad. This situation happened as a result from failure of developing ethical sensitivity in oneself. Meanwhile, in Turkey study, they found that most of their auditors are more idealistic individuals as compared to the USA auditors that are more relativist (Uyar and Ozer, 2011). So, it can be concluded that high or low in both idealism and relativism would defer based on the culture or environment.

Moreover, the results from scenario 1 and 2 showed a significant relationship between ethical sensitivity and ethical culture. The result is consistent with Sweeney et al. (2010) and Zakaria et al. (2009) whereby it was found that ethical culture had an impact on intention to engage in unethical behaviour. It indicates, when ethical culture is high, auditors' ethical sensitivity can improve the abilities to detect any ethical issue. Fang (2006) found that ethical culture has built up ethical perceptions and indirectly helps individuals in making ethical decisions because individuals are compulsory to follow the code of conduct being enforced in the audit firms.

However, this study did not find any significant relationship between internal or external locus of control and ethical sensitivity for both scenario 1 and 2 . This finding contradicted with the finding from the study by Lee (2013) who used the same questionnaire and the authors found that there was a significant positive relationship. Meanwhile, Appiah and Addai (2014) also found a positive relationship between locus of control and performance. The authors recommended programs of their organizations. In a study by Paino, Smith and Ismail (2012), they also found external locus of control is related to dysfunctional behaviour and it commits more unethical behaviour.

The inconsistency of result may be due to the culture of Malaysia or the target respondents as in this study, majority of the respondents are from audit assistants' level and 
fresh graduate. Maybe the problem to identify the ethical issue in the questionnaire might be difficult to them due to lack of experiences. Douglas et al. (2001) claimed that any differences in the ethical cases lead to different ethical decision-making process. Therefore, to avoid any ethical issue from arising, the new audit staff especially fresh graduates should join the training on ethics. By joining the ethics training, it can ensure the ethics development among the new auditors after leaving the university.

\section{Conclusions}

The financial scandals involving high profile companies around the world had frustrated the public expectations. There are many reported cases of fraud, corruption and mismanagement due to the auditors' unethical behaviour. Therefore, this study investigated the influences of firm culture, locus of control, and ethical orientation on the ethical sensitivity of auditors in Malaysia. It was found that ethical sensitivity has a significant negative relationship with relativism. This means that when relativism increased, ethical sensitivity decreased.

Besides that, ethical sensitivity also has a significant positive relationship with idealism. This indicated that when idealism in a person is increasing, ethical sensitivity also increases. Moreover, it was found a significant positive relationship between ethical sensitivity and ethical culture. Therefore, this study recommends developing good ethical culture in the organization to increase the ethical sensitivity among the auditors. By having strong ethical sensitivity, it is believed that auditors could help in mitigating the incidences of fraudulent financial reporting from happen or re-occur (Singh, Mohd. Hanefah and Kaur, 2018). At the same time, proper monitoring and establishing rules, guidelines and penalties for any auditors that are involved with unethical actions may improve the ethical sensitivity of the auditors.

This study has been conducted with several limitations such as the target respondents were auditors' who worked in Klang Valey that were selected randomly. Therefore, the selection of the respondents from the big four audit firms is small. For the future study, it should attempt to replicate and use larger and more varied samples of target respondents that focus on all auditors in Malaysia with a variety of different audit task conditions and scenario that is more relevant. This would enhance the external validity of the findings. Other limitation is regarding the distribution of the questionnaire. In this study, questionnaires were distributed via mail, which caused a lot of problems compared if it had been conducted in person such as giving them by hand. When the questionnaires were sent by mail, it was hard to ensure that the targeted subjects answered the questionnaires, there was no guarantee that the mail was forwarded back and no guarantee that the answers were truthful. Finally, it is also recommended to further investigate the issue in broader context to generalize the findings of the study.

\section{References}

Appiah, F.A and Addai, H. (2014), "An investigation into the causal relationship between employees' locus of control and contextual performance", Journal of Business and Behavioral Sciences, Vol. 26 No. 2, pp. 94-118.

Butterfield, K. D., L. K. Trevino and G. R. Weaver. (2000), "Moral awareness in business organizations: influences of issue-related and social context factors", Human Relations, Vol. 53, pp. 981-1018.

Cambridge Advanced Learner's Dictionary ( $3^{\text {rd }}$ Ed.). (2008). Cambridge University Press. 
Chadegani, A.A, Muhammaddun Mohammed, Z. and Mohd Iskandar, T. (2015), "The influence of individual characteristics on auditors' intention to report errors". Journal of Economics, Business and Management, Vol. 3 No. 7, pp. 710- 714.

Chan, S.Y.S. and Leung, P. (2006), "The effects of accounting students' ethical reasoning and personal factors on their ethical sensitivity", Managerial Auditing Journal, Vol. 21 No. 4, pp. $436-457$.

Chelariu, A., Horomnea, E., and Tanasa, F. (2014), "Education regarding ethics in the accounting profession - a literature review", European Integration - Realities and Perspectives, Vol. 9, pp. 372- 379.

Chen, J. and Silverthorne, C. (2008), "The impact of locus of control on job stress, job performance and job satisfaction in Taiwan", Leadership and Organization Development Journal, Vol. 29 No. 7, pp. 572-582.

Cohen, J. R., Pant, L. W. and Sharp, D. J. (2001), "An examination of differences in ethical decision-making between Canadian business students and accounting professionals", Journal of Business Ethics, Vol. 30, pp. 319-336.

Cohen, J.R., Pant, L.W. and Sharp, D.J. (1992), "Cultural and socio-economic constraints on international codes of ethics: lessons from accounting", Journal of Business Ethics, Vol. 1, pp. 678-700.

Dickerson, Carol. (2009), "Ethical decision making in public accounting: investigating factors that influence auditor ethical sensitivity", unpublished manuscript, Faculty of Education Claremont Graduate University, Claremont, United States.

Donnelly, D., Quirin, J. and O'Bryan, D. (2003), "Auditor acceptance of dysfunctional behavior: an explanatory model using auditors' personal characteristics", Behavioral Research in Accounting, Vol. 15 No. 1, pp. 87-110.

Douglas, P. C, Davidson, R. A., and Schwartz, B.N. (2001), "The effect of organizational culture and ethical orientation on accountants' ethical judgments", Journal of Business Ethics, Vol. 34, pp. 101-121.

Dreike, E. M. and Moeckel, C. (1995), "Perceptions of senior auditors: ethical issues and factors affecting actions", Research on Accounting Ethics, Vol. 1, pp. 331-348.

Fang, M.L. (2006), "Evaluating ethical decision-making of individual employees in organizations - an integration framework", Journal of American Academy of Business, Vol. 8 No. 2, pp. 105-113.

Field, A. P. (2005). Discovering statistics using SPSS, (2nd edition). London: Sage.

Firth, L., Mellor, D.J., Moore, K. and Cloude, L. (2004), "How can managers reduce employee intention to quit?", Journal of Managerial Psychology, Vol. 19, pp. 170-189.

Forsyth, D. R. (1980), “A taxonomy of ethical ideologies." Journal of Personality and Social Psychology, Vol. 39, pp. 175-184.

Gholami, K., and Tirri. K. (2012), "The cultural dependence of the ethical sensitivity scale questionnaire: the case of iranian kurdish teachers", Education Reaserch International. doi: $10.1155 / 2012 / 387027$.

Helliar, C., and Bebbington, K. J. (2004), "Taking Ethics to Heart." Institute of Chartered Accountants of Scotland.

Hunt, S.D., Wood, R., and Chonko, L.B., (1989), "Corporate ethical values and organizational commitment in marketing", Journal of Marketing,Vol. 53, pp.79-90.

Ismail, S. (2014), "Effect of ethical ideologies on ethical judgment of future accountants:Malaysian evidence", Asian Review of Accounting, Vol. 22 No. 2, pp.145 158.

Jackling, B., Cooper, B., Leung, P. and Dellaport, S. (2007), "Professional accounting bodies' perceptions of ethical issues causes of ethical failure and ethics education." Managerial Auditing Journal, Vol. 22 No. 9, pp. 928-944. 
Jeffrey, C., Weatherholt, N., and Lo, S. (2004), "Ethical development, professional commitment and rule observance attitudes: a study of auditors in Taiwan", The International Journal of Accounting, Vol. 31 No. 3, pp. 365-379.

Jenkins, J. G., D. R. Deis, J. C. Bedard and M. B. Curtis (2008), "Accounting firm culture and governance: a research synthesis", Behavioral Research in Accounting, Vol. 20, pp. 4574.

Johari, R. J., Mohd. Sanusi, Z. and Zarefar, A. (2019), “Auditor's ethical judgments: the influence of moral intensity, ethical orientation and client importance", International Journal of Financial Research, Vol. 10, No. 3, pp. 77-87.

Johari, R. J., Mohd-Sanusi, Z., and Vincent, K. C. (2017), "Effects of auditors' ethical orientation and self-interest independence threat on the mediating role of moral intensity and ethical decision-making process", International Journal of Auditing, Vol. 21 No. 1, pp. 38-58. https://doi.org/10.1111/ijau.12080

Jones, J., Massey, D. W. and Thorne, L. (2003), “Auditors' ethical reasoning: insights from past research and implications for the future." Journal of Accounting Literature, Vol. 22 , pp. 45-103.

Kalbers, L. P. and Fogarty, T. (2005), "Antecedents to internal auditor burnout", Journal of Managerial Issues, Vol. 17 No. 1, pp. 101-118.

Lee, H.W. (2013), "Locus of control, socialization, and organizational identification", Management Decision, Vol. 51 No. 5, pp. 1047-1055.

Leung, P., Cooper, B., Dellaportas, S., and Jackling, B. (2006), "Approaches to the development and maintenance of professional values, ethics and attitudes in accounting education programs", International Fedaration of Accountants, New York.

Marques, P. A., and Pereira, J. A. (2009), "Ethical ideology and ethical judgment in the Portuguese accounting profession", Journal of Business Ethics, Vol. 86, pp. 227-242.

Md. Zabid, R., and Saidatul, I. (2008), "The effect of culture and religiosity on business ethics: A cross-cultural comparison", Journal of Business Ethics, Vol. 82 No. 3, pp. 907-917.

Ozbek, V., Alniacik, U., Akkilic, M.E. and Koc, F. (2013), "The moderating role of locus of control on the links between perceived ethical problem and ethical intentions of marketing managers in Turkey", Procedia - Social and Behavioral Sciences, Vol. 99, pp. $265-273$.

Paino, H., Ismail, Z. and Smith, M. (2014), "Modelling dysfunctional behaviour: individual factors and ethical financial decision", Social and Behavioral Sciences, Vol. 145, pp. $116-128$.

Paino, H., Smith, M. and Ismail, Z. (2012), “Auditor acceptance of dysfuntional model using individual factors", Journal of Applied Accounting Research, Vol. 13 No. 1, pp. 37- 55.

Pallant J. (2007), "SPSS survival manual", Ligare Book Printer, Sydney.

Pierce, B. and Sweeney, B. (2005), "Management control in audit firms: partners' perspectives", Management Accounting Research, Vol. 16, pp. 340-370.

Rest, J. (1986), "Moral development: Advance in research and theory." New York: Praeger.

Rest, J. R. (1986), "Moral development: Advances in research and theory", Praeger, New York, USA.

Rotter, J. B. (1996), "Generalized expectancies for internal versus external control of reinforcement" Psychological Monographs: General and Applied, Vol. 80 No. 1, pp. 128.

Shaub, M., Finn, D. and Munter, P. (1993), "The effects of auditors' ethical orientation on commitment and ethical sensitivity", Behavioral Research in Accounting, Vol. 5, pp. 145-169. 
Shaub, M., Finn, D. and Munter, P. (1993), "The effects of auditors' ethical orientation on commitment and ethical sensitivity", Behavioral Research in Accounting, Vol. 5, pp. 145-169.

Shu, H.S. (2006), "Cultural differences in determining the ethical perception and decision making of future accounting professionals: a comparison between accounting students from Taiwan and the United States", The Journal of American Academy of Business Cambridge, Vol. 9 No. 1, pp. 147-158.

Singh, J., Mohd. Hanefah, M. and Kaur, K. (2018), "Humanise corporate governors eradicating accounting fraud by augmenting ethical sensitivity and religiosity in accounting education", Journal of Governance and Integrity, Vol. 2 No. 1, pp. 91-132.

Smith, M., Omar, N., Sayd Idris, S. I. Z. and Baharuddin, I. (2005), "Auditors' perception of fraud risk indicators: Malaysian evidence", Managerial Auditing Journal, Vol. 20 No. 1, pp. 73-85.

Spector, P. E. (1988), "Development of the work locus of control scale", Journal of Occupational Psychology, Vol.61, pp. 335-340.

Sweeney, B., Arnold, D., and Pierce, B. (2010), "The impact of ethical culture of the firm and demographic variables on auditors' ethical evaluation and intention to act decision", Journal of Business Ethics, Vol. 93, pp. 531-551.

Thorne, L. and Hartwick, J. (2001), "the directional effects of discussion on auditors' moral reasoning”, Contemporary Accounting Research, Vol. 18 No. 2, pp. 337-361.

Trevino, L. K., K. D. Butterfield and D. L. McCabe (1998), "The ethical context in organizations: influences on employee attitudes and behaviors", Business Ethics Quarterly, Vol. 8 No. 3, pp. 447-476.

Uyar, M. and Ozer, G. (2011), "The ethical orientation and professional commitment: An empirical examination on Turkish accountants", African Journal of Business Management, Vol. 5 No. 23, pp. 10023-10037.

Yusoff, Z. Z., Salleh, W.A., Zakaria, Z., Nair, G.K.S., Vadeveloo, T., and Luqman, A. (2011), "The influence of personal and organizational factors on ethical decision making intentions among managers", International Journal of Business and Management, Vol. 6 No. 9, pp. 261-270.

Zakaria, M., Haron, H. and Ismail, I. (2009), "Does organizational ethical climate influence auditors in perceiving ethical problems and forming ethical judgments?" Social and Management Research Journal, Vol. 6 No. 2, pp. 1-31. 
Appendix 1:

List of the items under each variable and related loading factor

\begin{tabular}{|c|c|c|c|}
\hline Variable & Item \# & Item Name & $\begin{array}{l}\text { Factor } \\
\text { Loading }\end{array}$ \\
\hline \multirow{7}{*}{ 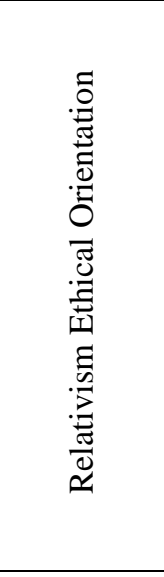 } & Relativism Q1 & $\begin{array}{l}\text { A code of ethics in an organization cannot be standardized } \\
\text { because what is right and wrong depend on individual } \\
\text { perspective. }\end{array}$ & 0.87 \\
\hline & Relativism Q2 & $\begin{array}{l}\text { Moral standards are based on individual judgment; one ethical } \\
\text { action might be seen as unethical by others. }\end{array}$ & 0.90 \\
\hline & Relativism Q3 & Ethical beliefs cannot be compared in term of their "rightness". & 0.87 \\
\hline & Relativism Q4 & $\begin{array}{l}\text { My ethical belief about what is right or wrong is only } \\
\text { applicable for me, and it cannot be compared to others. }\end{array}$ & 0.85 \\
\hline & Relativism Q5 & $\begin{array}{l}\text { I have no right to judge other people's action because my } \\
\text { moral principle applies only for me. }\end{array}$ & 0.88 \\
\hline & Relativism Q6 & $\begin{array}{l}\text { Individuals should be allowed to form their own standards } \\
\text { because ethical considerations vary from one person to another. }\end{array}$ & 0.86 \\
\hline & Relativism Q7 & $\begin{array}{l}\text { No standard of ethical action can be formulated; it depends } \\
\text { upon the situation surrounding the action. }\end{array}$ & 0.88 \\
\hline \multirow{7}{*}{ 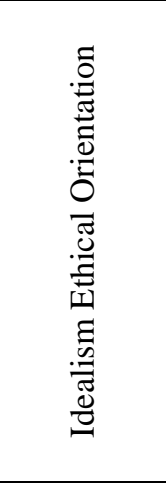 } & Idealism Q1 & $\begin{array}{l}\text { People should make certain that their actions never } \\
\text { intentionally harm other people even to a small degree. }\end{array}$ & 0.93 \\
\hline & Idealism Q2 & $\begin{array}{l}\text { Risks to other people should never be tolerated, irrespective of } \\
\text { how small the risks might be. }\end{array}$ & 0.86 \\
\hline & Idealism Q3 & $\begin{array}{l}\text { The existence of potential harm to other people should always } \\
\text { be avoided. }\end{array}$ & 0.88 \\
\hline & Idealism Q4 & $\begin{array}{l}\text { One should not perform an action which might threaten the } \\
\text { dignity and welfare of other people. }\end{array}$ & 0.89 \\
\hline & Idealism Q5 & $\begin{array}{l}\text { An action that could harm other people should never be } \\
\text { considered. }\end{array}$ & 0.91 \\
\hline & Idealism Q6 & The dignity and welfare of other people is my major concern. & 0.90 \\
\hline & Idealism Q7 & It is never necessary to sacrifice the welfare of other people. & 0.86 \\
\hline \multirow{8}{*}{ 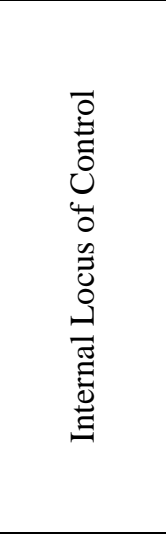 } & Internal Q1 & A job is what you make of it. & 0.55 \\
\hline & Internal Q2 & $\begin{array}{l}\text { On most jobs, people can pretty much accomplish whatever } \\
\text { they set out to accomplish. }\end{array}$ & 0.74 \\
\hline & Internal Q3 & $\begin{array}{l}\text { If you know what you want out of a job, you can find a job that } \\
\text { gives it to you. }\end{array}$ & 0.64 \\
\hline & Internal Q4 & $\begin{array}{l}\text { If employees are unhappy with a decision made by their boss, } \\
\text { they should do something about it. }\end{array}$ & 0.66 \\
\hline & Internal Q5 & Getting the job you want is mostly a matter of luck. & 0.54 \\
\hline & Internal Q6 & Making money is primarily a matter of good fortune. & 0.58 \\
\hline & Internal Q7 & $\begin{array}{l}\text { Most people are capable of doing their jobs well if they make } \\
\text { the effort. }\end{array}$ & 0.59 \\
\hline & Internal Q8 & $\begin{array}{l}\text { In order to get a really good job, you need to have family } \\
\text { members or friends in high places. }\end{array}$ & $0.49 *$ \\
\hline \multirow{8}{*}{  } & External Q1 & Promotions are usually a matter of good fortune. & 0.58 \\
\hline & External Q2 & $\begin{array}{l}\text { When it comes to landing a really good job, who you know is } \\
\text { more important than what you know. }\end{array}$ & 0.69 \\
\hline & External Q3 & $\begin{array}{l}\text { Promotions are given to employees who perform well on the } \\
\text { job. }\end{array}$ & 0.73 \\
\hline & External Q4 & To make a lot of money you have to know the right people. & 0.77 \\
\hline & External Q5 & $\begin{array}{l}\text { It takes a lot of luck to be an outstanding employee on most } \\
\text { jobs. }\end{array}$ & $0.38 *$ \\
\hline & External Q6 & People who perform their jobs well generally get rewarded. & $0.34 *$ \\
\hline & External Q7 & $\begin{array}{l}\text { Most employees have more influence on their supervisors than } \\
\text { they think they do. }\end{array}$ & 0.61 \\
\hline & External Q8 & $\begin{array}{l}\text { The main difference between people who make a lot of money } \\
\text { and people who make a little money is luck. }\end{array}$ & $0.34^{*}$ \\
\hline 总 & EC Q1 & $\begin{array}{l}\text { In my firm, I sometimes perceive that managers and partners } \\
\text { engage in behaviours that I consider to be unethical }\end{array}$ & 0.60 \\
\hline
\end{tabular}


EC Q2 In my firm, I sometimes perceive that senior auditors engage in behaviours that I consider to be unethical.

EC Q3 In my firm, I sometimes perceive that junior auditors engage in behaviours that I consider to be unethical.

EC Q4 In my firm, unethical behaviour is promptly reprimanded when discovered if it results in personal gain.

EC Q5

In my firm, unethical behaviour is promptly reprimanded when discoveredif it results in gain to the firm.

EC Q6 In order to succeed in my firm, it is sometimes necessary to compromiseone's ethics.

EC Q7 Top management in my firm has let it be known in no uncertain terms that unethical behaviours will not be tolerated. Often I feel that my firm's stance on ethics is just 'window

EC Q8 dressing' to maintain their public image and has no real substance.

Many auditors within my firm will often place 'business

EC Q9 pressures'(e.g. getting the audit done within time constraints or satisfying the client management etc.) ahead of the quality of the audit work.

EC Q10 My firm is known as a leader in promoting professional ethics within the profession (reversed).

On some occasions, I have been either explicitly or implicitly

EC Q11 pressured by supervisors in my firm to place the profitability of the audit firm ahead of the quality of audit work done.

* indicates the removed item where factor loading is below 0.5 


\section{Appendix 2: \\ List of Scenarios}

\section{Scenario 1:}

A public accounting firm has recently acquired a new client with a very low bid. The partner suggests the audit hour budget for inventory-related items will be 100 hours. The senior's experience with similar clients suggests that in order to have reasonable assurance of no material errors or irregularities, the audit will take a minimum of 150 hours. Performance evaluation is based in part on efficiency.

Action: The senior accepts the budget as is. The senior's plan is to do all necessary work to provide reasonable assurance but to underreport actual hours worked.

\section{Scenario 2:}

An audit client who also receives considerable tax services has a difference of opinion with the auditor as to when to recognize certain revenue transactions in which there is some uncertainty regarding the collectibility of the receivables. Recently a competitor soliciting auditing and tax services has approached the client. The firm has been a client for 20 years but has recently had a change in management.

Action: The partner in charge of the engagement accepts the client's interpretation of the receivables

Both of the scenarios followed with below questions:

\begin{tabular}{|c|c|c|c|c|c|c|}
\hline $\begin{array}{c}\text { Strongly } \\
\text { Disagree }\end{array}$ & Disagree & $\begin{array}{c}\text { Slightly } \\
\text { Disagree }\end{array}$ & $\begin{array}{c}\text { Neither Agree or } \\
\text { Disagree }\end{array}$ & Slightly Agree & Agree & $\begin{array}{c}\text { Strongly } \\
\text { Agree }\end{array}$ \\
\hline 1 & 2 & 3 & 4 & 5 & 6 & 7 \\
\hline
\end{tabular}

\begin{tabular}{|c|c|c|c|c|c|c|c|c|}
\hline & & 1 & 2 & 3 & 4 & 5 & 6 & 7 \\
\hline 1 & Most people would agree that the auditor's action is wrong. & & & & & & & \\
\hline 2 & This situation involves ethical issues. & & & & & & & \\
\hline 3 & $\begin{array}{l}\text { Are the issues within the scenario likely to have a significant impact } \\
\text { on the financial statements: }\end{array}$ & & & & & & & \\
\hline 4 & How important are the issues in the scenario? & & & & & & & \\
\hline
\end{tabular}

